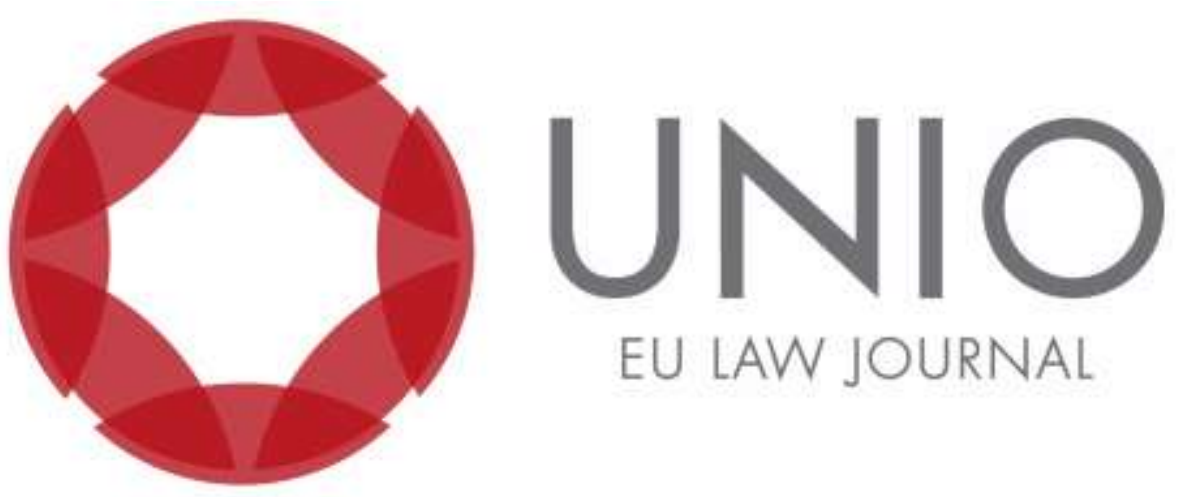

\title{
Agradecimento do Homenageado
}

\section{J. N. Cunha Rodrigues}

Ex-Juiz do Tribunal de Justiça da União Europeia

Este texto é o epílogo de um "discurso de resistência" a propósito da cessação das minhas funções no Tribunal de Justiça da União Europeia.

Doze anos de "exílio" numa das mais estimulantes etapas da minha vida profissional tinham-me feito sentir os efeitos do esquecimento e sugerido um regresso silencioso e anónimo.

Sabia, no entanto, que tinha Amigos indefetíveis e que, uma ou outra vez, era lembrado como alguém que dera o seu melhor ao serviço do país, numa época já então caracterizada por uma considerável erosão do Estado e da vontade coletiva.

Pensava poder beneficiar destas circunstâncias para retomar o ritmo dos dias, reconstituir laços de convívio e revisitar lugares comuns.

Surpreendentemente, um número considerável de Amigos, vindos de meios académicos e profissionais, decidiu evocar esta transição, com a organização de colóquios, de conferências e de coletâneas. 
Nuns casos, só tive conhecimento tardio das decisões e as minhas reticências apenas poderiam traduzir um desabafo, pois o movimento era imparável e tenho o sentido de gratidão. Noutros casos, porém, pude acompanhar a gestação da ideia.

Foi assim com a Escola de Direito da Universidade do Minho.

Os anos do Luxemburgo deram-me a oportunidade de viver uma das mais fascinantes e frutuosas experiências de cooperação com a Universidade, traduzidas especialmente na realização de seminários e visitas guiadas. Professores, magistrados, advogados e centenas de estudantes participaram nestas atividades, dando utilidade a esta janela de diálogo. Por outro lado, lancei constantemente mão da faculdade de abrir estágios, no meu Gabinete, a que naturalmente acederam juristas de países da União Europeia mas também, aproveitando a exceção prevista nos regulamentos do Tribunal, de países terceiros, de que destaco a Suíça, os Estados Unidos da América do Norte, a Nova Zelândia e a República Popular da China. A Escola de Direito da Universidade do Minho conquistou o direito a uma agenda anual, o que apenas se deve ao interesse manifestado pela Escola, ao empenhamento dos participantes e ao espírito indomável da Professora de Direito Comunitário e Diretora do Centro de Estudos em Direito da União Europeia, Doutora Alessandra Silveira.

Alessandra Aparecida Souza da Silveira tornou-se, para os meios comunitários do Luxemburgo, um exemplo de dinamismo, militantismo académico, curiosidade intelectual, capacidade organizativa e "jeito" obstinado e afetuoso para criar pontes, mobilizar vontades e demonstrar que ensinar e aprender é preciso.

Ora, é aqui que entronca o meu tempo de "resistência".

A Professora Alessandra Silveira manifestou-me cedo a sua intenção de organizar umas jornadas em minha homenagem. A minha resposta foi delicadamente desfavorável e, na minha disposição, era definitiva. Não só não via nenhum motivo para homenagens mas, sobretudo, custava-me aceitar que a iniciativa fosse vista como um gesto de reconhecimento quando a verdade é que o devedor era eu.

Os contactos que tínhamos entretecido tinham proporcionado trocas de opinião de grande valor e constituído oportunidade para intervenções, nomeadamente de juízes e de advogadosgerais, que refletiam, de forma pedagógica (o que beneficia quem aprende e quem ensina), o estado do Direito e da jurisprudência da União. 
A persistência da Professora Alessandra Silveira e a sua ductilidade argumentativa deixaramme, todavia, sem resposta, sobretudo quando outras Universidades tinham avançado com idênticos projetos.

Acabei por aceitar, renunciando a evasivas que tinham perdido sentido.

As jornadas de Braga foram um êxito.

A ideia, agora concretizada, de compilar os textos das intervenções então produzidas é a última fase do "processo".

E esta, independentemente do histórico que me envolve, é-me particularmente grata e vale a pena.

As intervenções possuem uma elevada densidade científica e abordam temas cruciais do Direito da União que ganharam contornos e acrescida importância com a crise.

A generalidade dos temas esteve presente em casos em que intervim e de que fui mesmo relator.

Nas linhas subsequentes, deixo o lastro que ficou de alguns casos, agora em que começo a ganhar perspetiva e a conhecer o valor das decisões pelos seus efeitos.

Como escrevi noutros lugares, referindo-me à questão da posição do Direito Comunitário, a dialética entre exigências existenciais e identidade nacional é intrínseca à arquitetura da União. Sessenta anos de polémicas e fraturas de pensamento sobre o princípio do primado conduziram-nos a uma saída cuja chave está na ideia de pluralismo constitutivo em que radica a ordem jurídica da União.

A multiculturalidade refletida nas modificações introduzidas pelo Tratado de Lisboa sugere um novo campo de observação obediente à acomodação e harmonização de princípios e atento às ideias de diferença, tolerância, aceitação e confiança. $\mathrm{O}$ apelo à noção de proeminência ou hierarquia que tanto parecia irritar os reticentes e os adeptos de novas construções dogmáticas, como as de soberania divisível ou de pós-soberania, têm agora um terreno fértil de especulação que, sem beliscar o princípio da aplicação preferencial do Direito da União, fica ao serviço da identidade e da coesão comunitária. O caminho foi longo e foram muitos os escolhos, como sucedeu com a questão dos direitos fundamentais que parecia resolvida com o acórdão Internationale Handelsgesellschaft mas tornou-se viral, até 
que a Carta dos Direitos Fundamentais da União Europeia e adesão à Convenção Europeia dos Direitos do Homem a tornou obsoleta.

A cooperação judiciária trouxe-nos, por seu lado, uma nova liberdade de circulação (de decisões) e vai funcionar como um fator de aproximação e de desmistificação da simbologia economicista do travejamento comunitário, num tempo que bem necessita deste instrumento, dados os efeitos da globalização e as tentativas, em alguns lugares bem-sucedidas, de desconstrução do Direito.

Os novos fluxos migratórios e a desregulamentação dos mercados estão carentes de Direito para proteger o homem europeu, "domesticar" o caos e refrear os interesses ilegítimos.

Estes temas encontram-se umbilicalmente ligados às questões da cidadania e da tutela jurisdicional efetiva. É, porventura, aqui que se joga o futuro da União.

Os últimos anos revelaram-se pródigos em decisões que pretendiam converter a cidadania da União em estatuto fundamental dos nacionais dos Estados-Membros, como prometeu o acórdão Grzelczyk. No entanto, a volatilidade foi a imagem de marca de alguma jurisprudência, por vezes limitada a postulados ou fragilizada por soluções de continuidade.

O desafio que agora se apresenta é de saber se as tensões provocadas pela crise terão reflexos na jurisprudência comunitária, fazendo-a reverter, ou se, pelo contrário, a cidadania europeia será reforçada e utilizada como fator de agregação e de aprofundamento, numa Europa cada vez mais dividida por fatores geográficos e económicos e atomizada pelo enfraquecimento do princípio de solidariedade.

Finalmente, a inclusão nos textos de caso Rinau prova a sensibilidade dos organizadores da coletânea e merece um aceno particular.

O caso comportava, por si próprio, três interrogações: como gerir o princípio do efeito útil numa situação de conflito entre jurisdições de diferentes Estados-Membros, como ajustar o tempo (histórico) da justiça às exigências do tempo (biológico) de uma criança e como ultrapassar o problema da multiplicidade e contraditoriedade de decisões que os expedientes processuais facilitam e que, em questões de tutela parental ou educativa podem prolongar os litígios ad nauseam.

Mas não são apenas estas interrogações que tornam o caso singular. Com ele, o olhar enche-se de cor: a de um Tribunal, habituado a questões de grande dimensão económica e 
complexidade jurídica "emocionado" com um pleito de humanidade, uma espécie de Kramer contra Kramer, em que o Direito se alia à equidade para fazer prevalecer a decisão do juiz que, segundo a legislação comunitária, está mais por dentro do conflito e é capaz de encontrar o lugar exato que resolve o interesse superior da criança. Pela primeira vez, a teia enchia-se de protagonistas de uma cena familiar que não "falava" "jurídico-economês", antes deixava perceber o dramatismo e o conflito de afetos de uma história simples. Nesse dia, poderia dizer-se que o Tribunal de Justiça tinha percecionado ao vivo quanto as suas competências tinham sido acrescentadas, ao serviço da cidadania.

As jornadas organizadas pela Escola de Direito do Minho encerram-se com esta publicação. Sobra-me o sentimento de que não me deviam ter tido por alvo. Consola-me a ideia de que fui pretexto para uma iniciativa exemplar, a vários títulos.

Agradeço à Escola, ao seu Presidente, ao seu corpo docente e aos seus alunos o terem dedicado imerecida atenção à minha pessoa.

Estou reconhecido, em particular, à Professora Doutora Alessandra Silveira, Querida Amiga, que encontrando-me, por vezes, distraído das coisas verdadeiramente importantes, levou a Escola até ao Tribunal de Justiça, trouxe o Tribunal de Justiça à Escola e, com limitados recursos, soube agilizar, num tempo de espera e sobressalto, o melhor das Instituições. 